Poznań

\title{
Czy parlament może zmienić mężczyznę w kobietę? Granice i miejsce zasady supremacji parlamentu w brytyjskim porządku konstytucyjnym wobec europejskich procesów integracyjnych (wybrane problemy) ${ }^{1}$
}

\section{Wprowadzenie}

$\mathbf{P}$ roblematyka brytyjskiego prawa ustrojowego jest przedmiotem zainteresowania wielu nie tylko europejskich konstytucjonalistów. Wynika to zapewne z większej niż „kontynentalna” złożoności brytyjskiej konstytucji ${ }^{2}$. Zasady znajdujące się w tzw. konstytucji niepisanej budzą ciekawość głównie ze względu na problem jej praktycznego zastosowania $^{3}$. Bardzo interesującym problemem wydaje się być wzajemna relacja elementów ustawy zasadniczej Zjednoczonego Królestwa, a także pozycja zasady supremacji parlamentu względem pozostałych części konstytucji, co będzie przedmiotem niniejszego artykułu. Problem ten wydaje się być nierozwiązywalny, o ile próbę jego rozwiązania podejmie się biorąc pod uwagę wyłącznie dyrektywy wynikające z prawniczej literatury konstytucjonalistów. Winna być ona uzupełniona o rozważania natury filozofii prawa czy też filozofii polityki.

Na samym początku należałoby wskazać części brytyjskiej konstytucji. Choć systematyka podziału nie jest jednoznaczna (nawet na płaszczyźnie semantycznej), to możemy dostrzec w polskiej literaturze naukowej pewne podobieństwo. Na potrzeby niniejszego artykułu przyjmijmy, że konstytucja Zjednoczonego Królestwa składa się z czterech części: norm prawa stanowionego ${ }^{4}$,

${ }^{1}$ Tytuł artykułu nawiązuje do stwierdzenia francuskiego badacza Jeana Louisa de Lolme, który stwierdził, że parlament brytyjski może zrobić wszystko oprócz zmiany kobiety w mężczyznę. Reakcją na to stwierdzenie była odpowiedź W. Ivora Jenningsa, że jak najbardziej Parlament może zmienić kobietę w mężczyznę w sensie prawnym, tak jak możliwe jest wydanie przez Parlament ustawy zakazującej palenia papierosów na ulicach Paryża oraz nakazu zabijania błękitnookich dzieci. S. Kubas, Parlament Szkocki. Dewolucja-wyzwanie dla Zjednoczonego Królestwa, Warszawa 2004, s. 35; A. Carroll, Constitutional and Administrative Law, Harlow 2011, s. 100.

2 J. Graham, E. C. Marques, Understanding Constitutions: A Roadmap for Communities, Ottawa 2000, s. 5.

${ }^{3} \mathrm{Na}$ samym początku warto zaznaczyć, że brak konstytucji pisanej w brytyjskim systemie politycznym nie jest równoznaczny z tym, że Zjednoczone Królestwo nie ma charakteru państwa konstytucyjnego. E. Gdulewicz, W. Kręcisz, Ustrój polityczny Wielkiej Brytanii, w: Ustroje państw współczesnych, red. W. Skrzydło, t. 1, Lublin 2010 , s. 15.

${ }^{4}$ Są to akty prawne stanowione współcześnie przez Parlament Zjednoczonego Królestwa, a wcześniej przez monarchę. Do najważniejszych aktów prawa stanowionego regulujących materię konstytucyjną należy zaliczyć: Magna Carta Libertatum, Petition of Right, Habeas Corpus Act, Bill of Rights, Act of Settlement, Parliament Act 1911, Crown Proceedings Act 1947, Life Peerage Act 1958, Peerage Act 1963, Parliamentary Commisioner Act 1967, European Communities Act 1972, Ministers of the Crown Act 1975, House of Commons Disqualification Act 1975, Senior Courts Act 1981, Tribunals and Inquiries Act 1992, Human Rights Act 1998, Scotland Act 1998, Government of Wales Act 1998, Northern Ireland Act 1998, House of Lords Act 1999, Freedom of Information Act 2000, Constitutional Reform Act 2005, Government of Wales Act 2006, Constitutional Reform and Governance Act 2010, Fixed-term Parliaments Act 2011.

Powyższe wyróżnienie aktów tworzących część konstytucji jest o tyle trudne, że ustalenie który akt stanowiony przez parlament należy uznać, za część konstytucji, a który takiego statusu posiadać nie będzie zależy w gruncie rzeczy od 
prawa zwyczajowego (common law) ${ }^{5}$, konwenansów (konwencji) konstytucyjnych ${ }^{6}$ oraz za- $^{-}$ sad ustrojowych. Przedmiotem niniejszego artykułu będzie element ostatniego składnika konstytucji - zasada suwerenności parlamentu.

Konsekwencją tak złożonego składu brytyjskiej konstytucji jest jednak bardzo prosta procedura jej zmiany. Brytyjska ustawa zasadnicza jest uznawana powszechnie za jedną z najbardziej elastycznych na świecie ${ }^{7}$, a ustawę o zmianie konstytucji przyjmuje się w takim samym trybie jak każdą inną ustawę publiczną.

\section{Zasady ustrojowe jako skladnik brytyjskiej konstytucji}

Powszechnie w literaturze wyróżnia się trzy zasady ustrojowe: zasadę podziału władzy, zasadę rządów prawa (rule of law) i zasadę supremacji parlamentu. Zasady te stanowią pewne generalne idee konstytucyjne, które w państwach posiadających pisane konstytucje są zapisane w pierwszych rozdziałach (często i w preambułach) ustaw zasadniczych. Są one swoistymi założeniami będącymi tworem ewolucji brytyjskiego prawa konstytucyjnego ${ }^{8}$. P. Sarnecki stwierdza, że zasady te nie mają charakteru zbioru twierdzeń apriorycznych, ale są wynikiem naukowej analizy i uogólnienia kilkuset lat funkcjonowania ustroju brytyjskiego ${ }^{9}$.

Zasada podziału władzy opiera się na organizacyjnym wymogu istnienia odrębnych organów władzy ustawodawczej, wykonawczej i sądowniczej. Nie oznacza to jednak, że owa odrębność musi być również spełniona $\mathrm{w}$ aspekcie personalnym ${ }^{10}$ czy też funkcjonalnym $^{11}$. Choć w kilku ostatnich latach możemy zaobserwować zmiany, jeżeli chodzi o aspekt personalny.

Z kolei zasada rządów prawa jest określana najczęściej jako przeciwieństwo rządów arbitralnych. Wyraża się ona w stwierdzeniu, że nie ma w Zjednoczonym Królestwie jakiegokol-

badacza, który kieruje się w tym wypadku wyłącznie kryterium materialnym, a nie formalnym. Warto podkreślić, że konstytucyjne akty prawne stanowione współcześnie przez Parlament Zjednoczonego Królestwa poza treścią materii, nie różnią się niczym od ustaw niezwiązanych z samym ustrojem politycznym państwa. Sam parlament nie wyróżnia w jakikolwiek sposób ustaw związanych z brytyjskim systemem politycznym. A. Pułło, Ustroje państw wspótczesnych, Warszawa 2006, s. 63.

${ }^{5}$ E. Gdulewicz i W. Kręcisz stoją na stanowisku, że zwyczajowe prawo konstytucyjne stanowi część prawa powszechnego (common law), które miało ukształtować się w opozycji do recepcji prawa rzymskiego. Z kolei M. Podolak określa tę część konstytucji nazwą prawo precedensowe. Autorzy sąjednak zgodni co do tego, że aksjomatami tej części konstytucji są zasady: suwerenności parlamentu oraz zasada the King can not a wrong. Dodać należy do tej listy jeszcze zasady: the King the can not act alone, instytucje prerogatyw monarszych i Tajną Radę oraz brak odpowiedzialności politycznej i konstytucyjnej głowy państwa. Zob. szerzej: M. Podolak, System polityczny Wielkiej Brytanii, w: Współczesne systemy polityczne, red. M. Żmigrodzki, B. Dziemidok-Olszewska, Warszawa 2007, s. 193; E. Gdulewicz, W. Kręcisz, Ustrój polityczny Wielkiej..., op. cit., s. 15-16.

${ }^{6}$ Konwenanse konstytucyjne to utarte i powszechnie uznane sposoby zachowania się w określonej sytuacji kształtujące się w drodze pewnego zwyczaju wynikającego z precedensów konstytucyjnych, czyli jednorazowych rozstrzygnięć związanych ze stosowaniem norm konstytucyjnych. Por. E. Gdulewicz, W. Kręcisz, Ustrój polityczny Wielkiej..., op. cit., s. 16.

${ }^{7}$ M. C. Elliot, The UK Parliament: Bicameralism, Sovereignty and the Unwritten Constitution, „International Journal of Constitutional Law" 2007, nr 5, s. 1-10.

${ }^{8}$ P. Sarnecki, Ustroje konstytucyjne państw współczesnych, Warszawa 2008, s. 18.

${ }^{9}$ Ibidem.

${ }^{10}$ Podręcznikowym wręcz przykładem jest umiejscowienie Lorda Kanclerza w brytyjskim systemie politycznym jako przewodniczącego obradom drugiej izby parlamentu (legislatywa), członka gabinetu (egzekutywa) i przewodniczącego Najwyższego Trybunału Apelacyjnego (judykatywa).

${ }^{11}$ M. Podolak, System polityczny Wielkiej..., op. cit., s. 194. 
wiek czynnika władzy publicznej, który nie byłby związany w swojej działalności prawem oraz nie byłby poddany kontroli i ocenie sądów powszechnych ${ }^{12}$.

\section{Zasada suwerenności parlamentu}

Genezy zasady suwerenności (zwierzchnictwa, supremacji, nadrzędności, omnipotencji) parlamentu należy szukać w okresie rozkwitu angielskiego parlamentaryzmu, tj. pod koniec XVII wieku, kiedy to doszło do pasma niekończących się sporów między monarchą a parlamentarzystami. Wtedy też stwierdzono, że parlament jako wyraziciel woli ludu ma prawo stanowić dowolne prawo ${ }^{13}$. W literaturze często przywołuje się słowa najwybitniejszego konstytucjonalisty brytyjskiego A. V. Dicey'a ${ }^{14}$ : „Zasada suwerenności parlamentu oznacza, że parlament [...] ma - w myśl angielskiej konstytucji - władzę tworzenia i znoszenia wszelkiego prawa" i w związku z tym nikt ,nie może unieważnić jego ustawodawstwa. W sensie pozytywnym zasada ta zapewnia, że każdy akt parlamentu będzie respektowany przez sądy. W sensie negatywnym oznacza, iż żadna jednostka ani gremium nie ma prawa wydawać przepisów, które byłyby sprzeczne z aktami parlamentu" ". Sama istota konstrukcji zasady w sposób dowcipny została ujęta przez Jeana Louisa de Lolme i W. Ivora Jenningsa, o czym wspomniano już na początku artykułu. Przejawami tej zasady mogą być m.in.:

— brak możliwości badania procedury uchwalania ustawy (i jakiegokolwiek innego aktu pochodzącego z parlamentu) przez jakikolwiek organ pozaparlamentarny;

— możliwość uchylenia przepisów już funkcjonujących w systemie prawnym;

- automatyzm zasady prawo późniejsze uchyla prawo wcześniejsze - nie jest wymagane formalne wskazanie które artykuły przestają obowiązywać;

- możliwość uchwalania aktów z mocą wsteczną;

— pierwszeństwo stosowania przepisów prawa brytyjskiego przed prawem międzynarodowym;

- brak ograniczenia terytorialnego - stąd teoretyczna możliwość uchwalenia ustawy zakazującej palenia na paryskich ulicach;

- określanie zasad dziedziczenia tronu;

— zredefiniowanie elementów brytyjskiego systemu politycznego - wobec odrzucenia w dwóch kolejnych sesjach projektu ustawy przez Izbę Lordów, ustawa otrzymuje sankcję królewską i staje się prawem; oznacza to, że de facto Parlament Zjednoczonego Królestwa w tym przypadku stanowi wyłącznie monarcha i Izba Gmin;

— określanie kategorii osób mogących wejść w skład obu izb parlamentu i długości trwania pełnomocnictw deputowanych do Izby Gmin;

- określanie wolności obywatelskich i praw człowieka ${ }^{16}$.

Prof. P. Sarnecki wyraża zdanie, że analizując treść zasady zwierzchnictwa parlamentu nie można jednak porównywać jego pozycji do pozycji absolutnego władcy ${ }^{17}$. Zdecydowanie należy zgodzić się z taką interpretacją zasady, zaznaczając tym samym, że parlament sprawu-

\footnotetext{
12 Ibidem, s. 193.

${ }^{13}$ Zob. szerzej: F. W. Maitland, The Constitutional History of England, Cambridge 1919, s. 297-301.

${ }^{14}$ Do tego autora często odwołują się zarówno współcześni konstytucjonaliści, jak i praktycy. Dzieła tego autora (w szczególności The Law of the Constitution) stanowią podstawę analizy brytyjskiej konstytucji.

${ }^{15}$ A. V. Dicey, Introduction to the Study of the Law of the Constitution, London 1915, s. 18-19.

${ }^{16}$ A. Carroll, Constitutional and Administrative..., op. cit., s. 96-103.

${ }^{17}$ P. Sarnecki (wstęp), Ustawy ustrojowe Zjednoczonego Królestwa Wielkiej Brytanii i Irlandii Pótnocnej, Warszawa 2010, s. 5.
} 
je swoją władzę nie w opozycji do poddanych Jej Królewskiej Mości, ale właśnie w ich imieniu (można nawet stwierdzić, że brytyjscy obywatele sprawują swoją władzę w Parlamencie Zjednoczonego Królestwa).

Część badaczy wskazuje zasadę suwerenności parlamentu jako jedyną zasadę występującą zarówno wśród zasad ustrojowych, jak i norm wywodzących się z prawa zwyczajowego $(\text { common law })^{18}$. Pokazuje to jak zasada ta jest głęboko zakorzeniona w brytyjskim ustroju politycznym. Z kolei inni badacze traktują zasadę suwerenności parlamentu jako jedną z trzech zasad ustrojowych, będących jednym z czterech części brytyjskiej konstytucji, co zostało już wcześniej wspomniane. W literaturze pojawia się również podejście, że zasada ta jest swego rodzaju zasadą ponadkonstytucyjną, stojącą ponad pozostałymi dwoma. Powstaje wobec tego pytanie: czy należy rozumieć, że same zasady ustrojowe funkcjonujące w brytyjskim systemie politycznym stoją ponad zasadą supremacji parlamentu, a brytyjski parlament nie jest w stanie bez naruszenia konstytucji dokonać zmiany jednej z zasad ustrojowych? Czy jednak zasada suwerenności parlamentu jest zasadą stojącą ponad wszystkie pozostałe normy konstytucyjne? Odpowiedzi na powyższe pytania zdają się udzielać E. Gdulewicz i W. Kręcisz, którzy stwierdzają jednoznacznie, że szeroki system źródeł prawa konstytucyjnego ma charakter niekonkurencyjny, a każdy element konstytucji ma jednakową moc prawną ${ }^{19}$. Autorzy wskazują, że wobec braku organu władzy sądowniczej odpowiedzialnego za kontrolę norm konstytucyjnych (można stwierdzić, że takim organem staje się w praktyce sam parlament). Należy podkreślić, że sędziowie są zobligowani do wykonania ustaw w formie przyjętej przez suwerena i nie mają prawa ich interpretacji ${ }^{20}$. Ów brak sądu konstytucyjnego, zdaniem autorów, powoduje, że brytyjską konstytucję należy uznać za elastyczną, wskazując jednak, że owa zmiana konstytucji powinna pociągać za sobą zgodę obywateli. Zgoda ta wyrażana jest z reguły poprzez poparcie partii dążącej do zmiany konstytucji (owa zmiana winna być zapisana w programie wyborczym) w wyborach powszechnych. Po uzyskaniu poparcia pozwalającego na objęcie rządów gabinet uzyskuje w praktyce prawo do wniesienia projektu ustawy, która doprowadzi do zmiany konstytucji. Podręcznikowym przykładem tak przeprowadzonej nowelizacji konstytucji wydaje się być chociażby dewolucyjna reforma konstytucyjna $\mathrm{z}$ końca lat $90 . \mathrm{XX}$ wieku ${ }^{21}$. Doprowadziła ona do kolejnej w historii ingerencji w zasadę suwerenności parlamentu (bo inne niż parlament ciała przedstawicielskie mogą tworzyć prawo). Do takich ingerencji dochodziło w historii wielokrotnie. Ostatnimi przykładami, poza reformą dewolucyjną, są przyjęte ustawy: European Communities Act 1972 (ustawa o Wspólnotach Europejskich z 1972 roku) i Human Rights Act 1998 (ustawa o prawach człowieka z 1998 roku). Ustawy te dopuściły inne niż Parlament Zjednoczonego Królestwa organy do stanowienia prawa. Ustawa o reformie konstytucyjnej (Constitutional Reform Act 2005), w 2009 roku odebrała Izbie Lordów funkcję orzekającą w postępowaniu sądowym.

Żeby zrozumieć zasadę suwerenności parlamentu, wyjść należy od założenia poczynionego przez P. Sarneckiego, wedle którego supremacja parlamentu znajduje swe konstytucyjno-

\footnotetext{
${ }^{18}$ Por. M. Podolak, System polityczny Wielkiej..., op. cit., s. 193.

${ }^{19}$ E. Gdulewicz, W. Kręcisz, Ustrój polityczny Wielkiej..., op. cit., s. 15.

${ }^{20} \mathrm{~W}$ praktyce doprowadza do wykształcenia się popularnej w państwach anglosaskich praktyki wydawania przez sądy orzeczeń precedensowych.

${ }^{21}$ Laburzyści w swoim programie wyborczym przed wyborami parlamentarnymi (maj 1997 r.) zapowiedzieli wprowadzenie pod obrady parlamentu projektów ustaw przekazujących (choć nie oddających) część kompetencji przysługujących do tej pory odpowiednim ministrom Korony i powołanie tym samym ciał przedstawicielskich (początkowo w Szkocji i Walii, a później i w Irlandii Północnej). Na temat dewolucji w Zjednoczonym Królestwie zob. szerzej: S. Kubas, Parlament Szkocki. Dewolucja-wyzwanie dla Zjednoczonego Królestwa, Warszawa 2004.
} 
prawne uzasadnienie w wizji parlamentu jako swoistej personifikacji ogółu obywateli ${ }^{22}$. Skoro jest więc tak, że na Narodzie (nazwanym w Zjednoczonym Królestwie poddanymi Jej Królewskiej Mości) spoczywa władza suwerenna, to parlament występuje jako uosobienie owego suwerena. Dlatego też podczas analizowania systemu politycznego Zjednoczonego Królestwa należy przyjmować, że w brytyjskim prawie konstytucyjnym zasada suwerenności parlamentu oznacza de facto konstytucyjną zasadę suwerenności Narodu ${ }^{23}$. Stąd nie można jej pod żadnym względem utożsamiać ze szwajcarską zasadą supremacji parlamentu ${ }^{24}$, która opiera się na Rousseau'owskiej zasadzie jednolitości władzy, stojąc tym samym w opozycji do Monteskiuszowskiej zasady trójpodziału władzy.

\section{Granice zasady suwerenności parlamentu wobec orzeczenia Izby Lordów w sprawie Jackson i inni vs. Prokurator Generalny JKM z 2005 roku}

Jednym z kolejnych problemów jest pytanie o granice zasady suwerenności parlamentu. Większość teoretyków brytyjskiego prawa konstytucyjnego stoi na stanowisku, że nie ma takiego prawa, którego nie mógłby uchwalić Parlament, a w praktyce każda nowo wybrana Izba Gmin (będąc jeszcze bardziej precyzyjnym sprowadzałoby się to do sprawowania rządów przez większość parlamentarną). Na takim stanowisku stoją zarówno konstytucjonaliści których rozprawy były i nadal są swego rodzaju uzupełnieniem brytyjskiej konstytucji (m.in. A. V. Dicey w klasycznym dziele An Introduction to the Study of the Law of Constitution, czy też W. Bagehot w pracy The English Constitution z 1873 roku), ale i współcześni badacze brytyjskiego prawa konstytucyjnego tacy chociażby jak V. Bogdanor czy J. Goldsworthy ${ }^{25}$. Możemy się jednak spotkać ze stanowiskiem zgoła odmiennym, wedle którego pomimo funkcjonowania fundamentalnej teorii konstytucyjnej suwerenność parlamentu ma swoje granice, a za ich kontrolę odpowiedzialne są sądy ${ }^{26}$. Wydaje się jednak, że opinie te są poglądami odosobnionymi i nieznajdującymi zrozumienia w brytyjskiej doktrynie prawnej.

Ważne (choć jak się wydaje nieprecedensowe) orzeczenie wydała w 2005 roku Izba Lordów $^{27}$, która rozpatrywała problem zastosowania ustaw z 1911 i 1949 roku (Parliament Act 1911 i Parliament Act 1949) w odniesieniu do przyjmowania prawa łowieckiego ${ }^{28}$. Izba

${ }^{22}$ P. Sarnecki (wstęp), Ustawy ustrojowe Zjednoczonego..., op. cit., s. 5.

${ }^{23}$ Do ciekawej konstatacji dochodzi K. Grzybowski, który wskazuje, że w zależności od przyjętej płaszczyzny analizy systemu konstytucyjnego suwerenem może okazać się lud (poddani JKM), Parlament, a można nie odnaleźć go wcale. To ostatnie rozwiązanie, choć interesujące, winno być jednak odrzucone. K. Grzybowski, Demokracja angielska, Kraków 1946, s. 29.

${ }^{24}$ Na temat zasady supremacji parlamentu zob. szerzej: Z. Czeszejko-Sochacki, System konstytucyjny Szwajcarii, Warszawa 2002, s. 45. Bardzo ciekawą opinię na temat pozycji szwajcarskiego parlamentu formułuje prof. P. Sarnecki: P. Sarnecki, Zgromadzenie Federalne - Parlament Konfederacji Szwajcarskiej, Warszawa 2003, s. 8-9.

${ }_{25}$ J. Goldsworthy, Parliamentary Sovereignty: Contemporary Debates, Cambridge 2010.

${ }^{26}$ H. Woolf, Droit Public - English Style, „Public Law” 1995, s. 69.

${ }^{27}$ Por. Opinia Lordów Najwyższego Trybunału Apelacyjnego w sprawie Jackson i inni vs. Prokurator Generalny Jej Królewskiej Mości z 13 października 2005 roku (Judgments - Jackson and others (appellants) v. Her Majesty's Attorney General (Respondent), House of Lords Session 2005-06 [2005] UKHL, 56 on appeal from: [2005] EWCA Civ 126. Na temat refleksji po wyroku Izby Lordów zob. szerzej: T. Mullen, Reflections on Jackson v Attorney General: questioning sovereignty, „Legal Studies” 2007, nr 1/27, s. 1-25.

${ }^{28}$ Przez blisko 7 lat Izba Lordów skutecznie blokowała możliwość zakazania popularnych w Anglii konnych polowań z psami na lisy. Izba Gmin w precedensowym rozstrzygnięciu odrzuciła przygotowany w parlamencie kompromis (na którego kształt miał wówczas wpływ rząd ówczesnego premiera Tony’ego Blaira, a miał polegać na jedynie ograniczeniu polowania na lisy poprzez koncesjonowanie tego sportu) i pomimo sprzeciwu drugiej izby par- 
Lordów potwierdziła konstytucyjną zasadę niemożliwości kwestionowania ważności ustaw (jak i procedury ich przyjmowania, co równie istotne) powtarzając tym samym sentencję wyroku Pickin vs. British Railways Board z 1974 roku: the courts in this country have no power to declare enacted law to be invalid (sądy w tym państwie nie mają żadnego prawa by uznawać przyjęte prawo za nieważne $)^{29}$. Stanowi to w zasadzie powtórzenie orzeczeń XIX-wiecznych, w których sądy również orzekały, że żaden organ władzy sądowniczej w państwie nie jest upoważniony do zakwestionowania aktu wydanego przez parlament ${ }^{30}$.

W orzeczeniu potwierdzono ponadto, że każda zmiana w ustroju wewnętrznym Izby Lordów (chociażby wspomniane już w ustawie z 1911 roku wprowadzenie powszechnych wyborów do tego organu) $)^{31}$ czy nawet jej usunięcie jest możliwe przy sprzeciwie wyższej izby brytyjskiego parlamentu. W wyroku apelacyjnym sąd stwierdził, że wszelkie zmiany konstytucyjne nie powinny być przeprowadzane przez Izbę Gmin z wykorzystaniem procedury wskazanej w ustawie z 1911 roku, gdyż stałoby to w sprzeczności z intencjami ustawodawcy ${ }^{32}$. Żadna z instancji, włączając Izbę Lordów, nie zakwestionowała jednak legalności ustawy o łowiectwie ${ }^{33}$.

Orzeczenie miało ogromne znaczenie dla brytyjskiego prawa konstytucyjnego, bowiem o ile potwierdzona została zasada suwerenności parlamentu i zasada rządów prawa, a także szczegółowa reguła zakazująca badania ustaw przez sędziów, o tyle charakter nieograniczoności zasady supremacji parlamentu został w pewnym sensie poddany krytycznej analizie. Baronessa Brenda Hale stwierdziła, że zasada suwerenności parlamentu jako siedemnastowieczna reguła rządząca ustrojem politycznym Anglii i Walii została obecnie w jakimś stopniu ograniczona poprzez przystąpienie do Wspólnot Europejskich (i przyjęcie European Communities Act 1972) i uchwalenie Human Rights Act 1998. Baronessa słusznie, jak się wydaje, stwierdza jednak, że owo samoograniczenie władzy parlamentu jest bardziej aktem politycznym niż konstytucyjnym ${ }^{34}$. Wiąże się to bowiem z regułą wywodzącą się z zasady supremacji parlamentu, wedle której nikt, nawet Parlament Zjednoczonego Królestwa, nie może wiązać swoją decyzją „przyszłych Parlamentów”35.

\section{Granice zasady suwerenności parlamentu wobec przystąpienia Zjednoczonego Królestwa do Wspólnot Europejskich}

Problem zmiany w klasycznym pojmowaniu zasady supremacji parlamentu pojawił się z chwilą włączenia Zjednoczonego Królestwa w struktury Wspólnot Europejskich. Polegał

lamentu, Izba Gmin uchwaliła ponownie kontrowersyjną ustawę. Posłowie skorzystali przy tym z zapisów ustaw z 1911 i 1949 roku, które umożliwiają uchwalenie ustawy innej niż finansowa (i przedłużającej pełnomocnictwa posłów) pomimo sprzeciwu Izby Lordów.

${ }^{29}$ Opinia Lordów Najwyższego Trybunału..., op. cit., pkt 27.

${ }^{30}$ A. Bradley, The Sovereignty of Parliament-form or substance?, w: The Changing Constitution, red. J. Jowell, D. Oliver, Oxford 2000, s. 27.

${ }^{31}$ Parliament Act 1911, preambuła.

${ }^{32}$ Wyrok Wydziału Cywilnego Sądu Apelacyjnego w Sądzie Najwyższym Anglii i Walii z 16 lutego 2005 roku, In the Supreme Court of Judicare - Court of Appeal (Civil Division) on appeal form the Administrative Court, [2005] EWCA Civ 126, Case No: C1/2005/0201, 16 February 2005, punkt 41.

${ }^{33}$ Skarga do Europejskiego Trybunału Praw Człowieka w Strasburgu nie przyniosła skutku. Por. Decision on admissibility: Friend v. the United Kingdom (application no. 16072/06) and Countryside Alliance and Others v. the United Kingdom (no. 27809/08); Unanimously: applications inadmissible, Ban on hunting with hounds - complaints rejected, nr 964 z 15.12.2009 r.

${ }^{34}$ Opinia Lordów Najwyższego Trybunału..., op. cit., pkt 159.

${ }^{35}$ H. Barnett, R. Jago, Constitutional \& Administrative Law, London 2011, s. 151. 
(i nadal polega) on na konflikcie dwóch nadrzędnych reguł: (brytyjskiej) zasady suwerenności parlamentu i (wspólnotowej) zasady prymatu prawa wspólnotowego względem prawa krajowego. W związku z tym, że klasyczna zasada supremacji parlamentu nie przewiduje żadnego innego organu, który mógłby stanowić prawo obowiązujące na terytorium Królestwa, przyjęto - jak się wydaje - jedyne możliwe rozwiązanie: uchwalono European Communities Act, która to ustawa przewidywała obowiązywanie prawa wspólnotowego na terytorium Zjednoczonego Królestwa ${ }^{36}$. Kwestią czasu była kolizja prawa krajowego ze wspólnotowym. Gdy wreszcie do takiego konfliktu doszło, sądy zaczęły tak interpretować prawo krajowe ${ }^{37}$, by nie zostać posądzone o orzekanie niezgodne z porządkiem prawnym krajowym i wspólnotowym. Wymagało to skorzystania z celowościowej interpretacji prawa, która była niemal całkowicie obca brytyjskiemu sądownictwu (ze względu na ryzyko oskarżenia o nieuprawnioną uzurpację kompetencji władzy ustawodawczej) $)^{38}$.

Przełomem okazało się orzeczenie wydane w 1990 roku przez Izbę Lordów, która jako ostatnia instancja w postępowaniu sądowym orzekła, że jedna z ustaw parlamentu jest niezgodna z prawem wspólnotowym, tym samym po raz pierwszy w tak otwarty sposób zasada suwerenności parlamentu została zakwestionowana. Orzeczenie otworzyło tym samym możliwość brytyjskim sądom na badanie aktów stanowionych przez parlament w odniesieniu do ich relacji z aktami prawa wspólnotowego. Ponadto, sądy mogły, w przypadku stwierdzenia niezgodności aktu prawa krajowego ze wspólnotowym, odmówić stosowania tego pierwszego ${ }^{39}$.

W 2011 roku, wobec nastrojów eurosceptycznych w Wielkiej Brytanii (a w szczególności wobec woli spełnienia obietnicy przedwyborczej konserwatystów), przyjęto ustawę o Unii Europejskiej (European Union Act 2011), gdzie potwierdzono prymat zasady suwerenności parlamentu ${ }^{40}$. W art. 18 tejże ustawy zapisano, że prawo Unii Europejskiej jest bezpośrednio stosowane i jest skuteczne na terytorium Zjednoczonego Królestwa tylko na podstawie ustawy ${ }^{41}$.

\section{Pozycja zasady suwerenności parlamentu względem pozostałych części konstytucji}

Jak zostało wspomniane wcześniej, nie ma konsensusu co do tego, czy zasada suwerenności parlamentu jest jedynie jedną z trzech zasad ustrojowych, czy jest może zasadą ponadkonstytucyjną stojącą zarówno ponad dwiema pozostałymi zasadami ustrojowymi, ale i ponad pozostałymi częściami konstytucji brytyjskiej. V. Bogdanor stwierdza, że owa fundamentalna zasada jest może nawet zasadą jedyną ${ }^{42}$.

${ }^{36}$ Dla części badaczy wstapienie do struktur WE/UE oznacza upadek doktryny absolutnej suwerenności parlamentu. A. Jassem, Wielka Brytania a Wspólnoty Europejskie: aspekty ustrojowo-polityczne, „Studia Europejskie” 2003, nr 25-26, s. 64.

${ }^{37}$ I. Loveland, Parliamentary Sovereignty, „Parliamentary Affairs” 1994, nr 4, s. 522-523.

38 A. Jassem, Wielka Brytania a Wspólnoty..., op. cit., s. 64.

${ }^{39}$ D. Chalmers, The Positioning of EU Judicial Politics within the United Kingdom, ,West European Politics” 2000, nr 4/23, s. 173 .

${ }^{40}$ Ustawa składa się z trzech części: w pierwszej znalazły się zapisy odnośnie konieczności przeprowadzenia referendum w przypadku zmian traktatowych, w drugiej - kwestii wyborów posłów do Parlamentu Europejskiego, a w ostatniej - status relacji między prawem brytyjskim a unijnym.

${ }^{41}$ Directly applicable or directly effective EU law [...] falls to be recognised and available in law in the United Kingdom only by virtue of that Act or where it is required to be recognised and available in law by virtue of any other Act. European Union Act 2011, art. 18.

${ }^{42}$ V. Bogdanor, Devolution in the United Kingdom, Oxford 1999, s. 1. 
Nie podlega wątpliwości, że parlament może uchwalić każde prawo, które doprowadzi do utrwalenia pewnego zwyczaju w drodze ustawy lub też taki zwyczaj usunie z brytyjskiego porządku prawnego. Dlatego w przypadku kolizji konwenansów (konwencji) konstytucyjnych z zasadą suwerenności parlamentu czy też aktami prawa stanowionego, konwencje stoją niżej.

Ciekawie wygląda sytuacja kolizji prawa stanowionego z prawem powszechnym. Konstytucjonaliści wskazują jednoznacznie, że w przypadku wprowadzenia do systemu prawnego przez parlament jednoznacznego przepisu prawnego, stojąca z nim w sprzeczności reguła wynikająca z prawa powszechnego (jak i norma equity) staje się nieważna ${ }^{43}$. Wydaje się, że ten sposób rozwiązywania konfliktów między dwiema normami ma źródło właśnie w zasadzie supremacji parlamentu: skoro suweren (obywatele reprezentowani w parlamencie) posiada najwyższą władzę w państwie, to każda norma prawna, która stoi w sprzeczności z jego wolą winna móc być zmieniona lub usunięta. Jak stwierdzili S. E. Finer, V. Bogdanor i B. Rudden, brytyjska konstytucja jest bezładnq mieszanina ustaw, [...] konwenansów, [...] norm prawa zwyczajowego i precedensów sqdowych. Jedyne, czego w tym bałaganie możemy być pewni, to prymat ustaw nad regulacjami pozaustawowymi, a w odniesieniu do samych ustaw - prymat aktów późniejszych nad wcześniejszymi ${ }^{44}$. Autorzy wskazali tym samym dwa elementy wchodzące w skład omawianej zasady supremacji parlamentu: prawo stanowione przez Parlament Zjednoczonego Królestwa stoi ponad wszystkimi innymi regulacjami konstytucyjnymi oraz to, że prawo stanowione przez jeden parlament, nie może ograniczać w swych postanowieniach parlamentów kolejnych „kadencji”.

Z kolei w przypadku kolizji prawa stanowionego z zasadą supremacji parlamentu, rację winno się przyznać zasadzie suwerenności, ponieważ, jak stwierdza S. Kubas, odwołując się do podejścia O. Hooda Phillipsa, P. Jacksona i P. Leopolda: supremacja Parlamentu zostaje uznana za fundamentalne prawo brytyjskiej konstytucji, niepodlegajace zmianie [nawet - M. Ł.] przez Parlament ${ }^{45}$.

Jedna $\mathrm{z}$ trzech zasad ustrojowych, zasada podziału władzy, w sposób oczywisty podlega procesowi nieustannej zmiany w ciagu ostatnich kilkunastu lat. Klasycznym przykładem potwierdzającym ową tezę jest reforma Izby Lordów. Do 2005 roku w osobie sprawującej urząd Lorda Kanclerza (Lord High Chancellor of Great Britain) łączyły się trzy władze: legislatywa, egzekutywa i judykatywa. W wyniku przyjęcia ustawy o reformie konstytucyjnej z 2005 roku (Constitutional Reform Act 2005), Lord Kanclerz przestał stać na czele brytyjskiej władzy sądowniczej i utracił prawo przewodniczenia obradom Izby Lordów (powołano urząd Lorda Speakera wybieranego spośród parów), a także powstał nowy organ Korony - Sąd Najwyższy Zjednoczonego Królestwa (Supreme Court of the United Kingdom), który działa od 1 października 2009 roku $^{46}$. Konstytucjonalizacja tego organu doprowadziła do znacznego ograniczenia sądowniczej roli Izby Lordów jako ostatecznej instancji w postępowaniu sądowym ${ }^{47}$.

\footnotetext{
${ }^{43}$ Por. A. Meszorer, Brytyjski system parlamentarny w zarysie, Warszawa 1962, s. 67; L. Konic, Ogólne cechy „Equity”, „Państwo i Prawo” 1947, nr 44, s. 30 i n.; W. V. Jennings, The Law and the Constitution, London 1959, S. $153-154$.

${ }^{44}$ S. E. Finer, V. Bogdanor, B. Rudden, Comparing Constitutions, Oxford 1995, s. 40-42.

${ }^{45}$ S. Kubas, Parlament Szkocki. Dewolucja - wyzwanie dla..., op. cit., s. 34; O. Hood Phillips, P. Jackson, P. Leopold, Constitutional and Administrative Law, London 2001, s. 60.

${ }^{46}$ D. Woodhouse, United Kingdom The Constitutional Reform Act 2005 - defending judicial independence the English way, „Int J Constitutional Law” 2007, nr 5(1), s. 153-165.

${ }^{47}$ Zob. szerzej: K. Urbaniak, Projekt bezpośrednich wyborów do brytyjskiej Izby Lordów, w: Prawo wyborcze i wybory. Doświadczenia dwudziestu lat procesów demokratyzacyjnych w Polsce, red. A. Stelmach, Poznań 2010, s. $271-281$.
} 
Jednym z nierozwiązywalnych problemów wydaje się być funkcjonowanie w konstytucji dwóch segmentów: zasady rządów prawa i zasady suwerenności parlamentu ${ }^{48}$. Takiej sytuacji nie przewidywał A. V. Dicey, który uważał, że zasady te wzajemnie się uzupełniają, a zasada suwerenności wspiera zasadę rządów prawa ${ }^{49}$. Jednym z najważniejszych przykładów konfliktu tych dwóch zasad konstytucyjnych była sprawa ustawy o łowiectwie. A. Badley wskazuje, że właśnie wtedy trzech lordów w ramach obiter dictum, poddała badaniu relację obu zasad, co nigdy wcześniej nie miało miejsca ${ }^{50}$. Swego rodzaju próbą wyjścia z tego problemu wydaje się być ustawa o prawach człowieka (Human Rights Act), która kładzie nacisk na konieczność dialogu między trzema ośrodkami władzy: rządem, parlamentem i sądami ${ }^{51}$.

\section{Podsumowanie}

W ustawie z 2011 roku o Unii Europejskiej (European Union Act 2011) zapisano obowiązek przeprowadzania głosowania ludowego w sprawie każdej kolejnej zmiany Traktatu o Unii Europejskiej i Traktatu o Funkcjonowaniu Unii Europejskiej przez każdy kolejny rząd. Stoi to w oczywistej sprzeczności z zasadą suwerenności parlamentu, gdyż ogranicza parlament przyszłych kadencji i zmusza do przeprowadzenia referendum połączonego z pracami $\mathrm{w}$ parlamencie zamiast przeprowadzenia tej procedury jedynie w organie przedstawicielskim. Ale w takiej samej sprzeczności z tą zasadą stoją założenia ustawy z 1972 roku (European Communities Act 1972), co winno skłaniać do stwierdzenia, że zasada supremacji parlamentu, w obliczu procesów integracyjnych uległa znaczącej modyfikacji i choć nadal jest fundamentem brytyjskiej konstytucji, to jej interpretacja nie pozwala już na określenie jej mianem zasady absolutnej supremacji parlamentu ${ }^{52}$.

Ciekawa wydaje się ewentualna ewolucja interpretacji zasady supremacji parlamentu w brytyjskiej myśli prawnej. Nie podlega wątpliwości, że do owej ewolucji musi dojść ze względu na wskazane wyżej przesłanki. Należy w tym miejscu zgodzić się z A. Stępkowskim, że proces przenoszenia kompetencji z parlamentu na inne organy, którego finalną postacią będzie synteza amerykańskiego judical review i rozwiązań ustrojowych typowych dla państw

\footnotetext{
${ }^{48}$ Na problem ten zwraca uwagę bez wątpienia współcześnie jeden z najwybitniejszych konstytucjonalistów brytyjskich, prof. Vernon Bogdanor. Zob. szerzej: V. Bogdanor, Courts and the Making of Public Policy: The Conflict between Government and the Judges, The Foundation for Law, Justice and Society in collaboration with The Centre for Socio-Legal Studies, University of Oxford, s. 2-8.

${ }^{49}$ The sovereignty of Parliament [...] favours the supremacy of the law, whilst the predominance of rigid legality throughout our institutions evokes the exercise, and thus increases the authority, of Parliamentary sovereignty. A. V. Dicey, Introduction to the Study of..., op. cit., s. 402.

${ }^{50}$ A. Bradley stwierdza, że może upłynąć jeszcze trochę czasu, aż prowokacyjna legislacja i odwaga sędziów doprowadzi do otwartego, bezpośredniego potwierdzenia prymatu zasady rządów prawa nad zasadą suwerenności parlamentu przez sądy, ale trzeba przyznać, że obecnie nie jest już tak oczywiste, że współczesny ustawodawca może bezkarnie naruszać struktury zasady rządów prawa. A. Bradley, The Sovereignty of Parliament - form..., op. cit., s. 23.

${ }^{51}$ Prof. Bogdanor przywołuje anegdotę, wedle której miał profesor kiedyś zapytać pewnego wysokiego rangą sędziego co stałoby się gdyby doszło do kolizji zasady suwerenności parlamentu i zasady rządów prawa (rule of law). Ten miał odpowiedzieć, że jest to pytanie, które nie powinno być zadawane, wskazując tym samym na jedynie teoretyczną możliwość takiego konfliktu, ale i jednocześnie na brak uregulowań przewidujących następstwa takiej kolizji. Por. V. Bogdanor, Courts and the Making of ..., op. cit., s. 4.

${ }^{52}$ V. Bogdanor stoi na stanowisku, że idea tak wspierana przez A. V. Diceya była konstrukcją abstrakcyjną, modelem, i w praktyce nieosiaggalnym. V. Bogdanor, The New British Constitution, Oxford-Portland 2009, s. 273.
} 
Europy kontynentalnej wydaje się być jedynie kwestią czasu ${ }^{53}$. Jego przebieg winien być przedmiotem analiz.

\section{Bibliografia}

Barnett H., Jago R., Constitutional \& Administrative Law, London 2011.

Bogdanor V., Devolution in the United Kingdom, Oxford 1999.

Bogdanor V., The New British Constitution, Oxford-Portland 2009.

Bradley A., The Sovereignty of Parliament-form or substance?, w: The Changing Constitution, red. J. Jowell, D. Oliver, Oxford 2000.

Carroll A., Constitutional and Administrative Law, Harlow 2011.

Chalmers D., The Positioning of EU Judicial Politics within the United Kingdom, „West European Politics” 2000, nr $4 / 23$.

Dicey A. V., Introduction to the Study of the Law of the Constitution, London 1915.

Elliot M. C., The UK Parliament: Bicameralism, Sovereignty and the Unwritten Constitution, „International Journal of Constitutional Law" 2007, nr 5.

European Union Act 2011.

Finer S. E., Bogdanor V., Rudden B., Comparing Constitutions, Oxford 1995.

Gdulewicz E., Kręcisz W., Ustrój polityczny Wielkiej Brytanii, w: Ustroje państw współczesnych, red. W. Skrzydło, t. 1, Lublin 2010.

Gebethner S., Systemy polityczne, Warszawa 1971.

Goldsworthy J., Parliamentary Sovereignty: Contemporary Debates, Cambridge 2010.

Graham J., Marques E. C., Understanding Constitutions: A Roadmap for Communities, Ottawa 2000.

Grzybowski K., Demokracja angielska, Kraków 1946.

Hood Phillips O., Jackson P., Leopold P., Constitutional and Administrative Law, London 2001.

In the Supreme Court of Judicare - Court of Appeal (Civil Division) on appeal form the Administrative Court, [2005] EWCA Civ 126, Case No: C1/2005/0201, 16 February 2005.

Jassem A., Wielka Brytania a Wspólnoty Europejskie: aspekty ustrojowo-polityczne, „Studia Europejskie” 2003, nr 25-26.

Jennings W. V., The Law and the Constitution, London 1959.

Judgments - Jackson and others (appellants) v. Her Majesty's Attorney General (Respondent), House of Lords Session 2005-06 [2005] UKHL, 56 on appeal from: [2005] EWCA Civ 126.

Konic L., Ogólne cechy „Equity”, „Państwo i Prawo” 1947, nr 44.

Kubas S., Parlament Szkocki. Dewolucja - wyzwanie dla Zjednoczonego Królestwa, Warszawa 2004.

Loveland I., Parliamentary Sovereignty, „Parliamentary Affairs” 1994, nr 4.

Maitland F. W., The Constitutional History of England, Cambridge 1919.

Meszorer A., Brytyjski system parlamentarny w zarysie, Warszawa 1962.

Mullen T., Reflections on Jackson v Attorney General: questioning sovereignty, „Legal Studies” 2007, nr 1/27.

Parliament Act 1911.

Podolak M., System polityczny Wielkiej Brytanii, w: Współczesne systemy polityczne, red. M. Żmigrodzki, B. Dziemidok-Olszewska, Warszawa 2007.

Pułło A., Ustroje państw współczesnych, Warszawa 2006.

Sarnecki P. (wstęp), Ustawy ustrojowe Zjednoczonego Królestwa Wielkiej Brytanii i Irlandii Pólnocnej, Warszawa 2010.

Sarnecki P., Ustroje konstytucyjne państw współczesnych, Warszawa 2008.

Sarnecki P., Zgromadzenie Federalne - Parlament Konfederacji Szwajcarskiej, Warszawa 2003.

\footnotetext{
${ }^{53}$ A. Stępkowski, Zasada proporcjonalności w europejskiej kulturze prawnej. Saqdowa kontrola władzy dyskre-
} cjonalnej w nowoczesnej Europie, Warszawa 2010, s. 111. 
Stępkowski A., Zasada proporcjonalności w europejskiej kulturze prawnej. Sąowa kontrola władzy dyskrecjonalnej w nowoczesnej Europie, Warszawa 2010.

Urbaniak K., Projekt bezpośrednich wyborów do brytyjskiej Izby Lordów, w: Prawo wyborcze i wybory. Doświadczenia dwudziestu lat procesów demokratyzacyjnych w Polsce, red. A. Stelmach, Poznań 2010.

Woodhouse D., United Kingdom The Constitutional Reform Act 2005 - defending judicial independence the English way, „Int J Constitutional Law” 2007, nr 5(1).

Woolf H., Droit Public - English Style, „Public Law” 1995.

\title{
Can a parliament change a man into a woman? The limits and location of the principle of parliamentary supremacy in the British constitutional order in relation to European integration processes (selected issues)
}

\begin{abstract}
Summary
The political system of the United Kingdom of Great Britain and Northern Ireland is of interest to researchers for several reasons. One of the most important motivations certainly involves the unique construction of its Constitution, the content of which is not formulated in a single legal act of a supreme status. This unwritten Constitution encompasses at least four parts. The most important part is undoubtedly constituted by one of three principles of the political system, namely the principle of the sovereignty (omnipotence) of parliament. This principle, which is regarded as a constitutional principle by some and as a principle above the Constitution by others, constitutes the core of British constitutional law.

The topic of this paper is an attempt to indicate the boundaries of this principle in the British constitutional order and to place it in relation to remaining principles. The boundaries of this principle have been considered by British constitutionalists on numerous occasions. Considerations on the relation of this principle to the remaining elements of the Constitution have been the subject of interest for courts of law, including the House of Lords, which used to function as the court of last instance in judicial proceedings prior to the 2005 reform. It is worth emphasizing that even the lords/judges frequently disagreed on the boundaries of the principle and even on whether the principle can be examined by any court. There were also views that the principle is only a virtual construct, and even if it had ever applied to the political system at all, it can no longer be referred to, given contemporary European integration processes.

The complicated combination of elements of the British constitution with the presence of the United Kingdom in the structures of the European Council and European Union (preceded by the European Community) have produced a number of interpretations of the principle of the omnipotence of the parliament in the new political reality the UK has found itself in. It was the adoption of the European Communities Act 1972, followed several decades later by the adoption of the European Union Act 2011 that led to the discussion on the construction of the British Constitution and either the approval or rejection of the concept that the Constitution of the United Kingdom with its meta-principle should be interpreted anew.
\end{abstract}


